\title{
Revisiting the social organisation of national memory: a look at the calendars of Lithuania, Latvia, and Estonia.
}

DOI:

$10.1177 / 1750698018784116$

\section{Document Version}

Accepted author manuscript

Link to publication record in Manchester Research Explorer

\section{Citation for published version (APA):}

Andrejevs, D. (2018). Revisiting the social organisation of national memory: a look at the calendars of Lithuania, Latvia, and Estonia. Memory Studies. https://doi.org/10.1177/1750698018784116

\section{Published in:}

Memory Studies

\section{Citing this paper}

Please note that where the full-text provided on Manchester Research Explorer is the Author Accepted Manuscript or Proof version this may differ from the final Published version. If citing, it is advised that you check and use the publisher's definitive version.

\section{General rights}

Copyright and moral rights for the publications made accessible in the Research Explorer are retained by the authors and/or other copyright owners and it is a condition of accessing publications that users recognise and abide by the legal requirements associated with these rights.

\section{Takedown policy}

If you believe that this document breaches copyright please refer to the University of Manchester's Takedown Procedures [http://man.ac.uk/04Y6Bo] or contact uml.scholarlycommunications@manchester.ac.uk providing relevant details, so we can investigate your claim.

\section{OPEN ACCESS}




\author{
Name: \\ Dmitrijs Andrejevs \\ Affiliation: \\ University of Manchester \\ Address: \\ Department of Russian and East European Studies \\ School of Arts, Languages and Cultures \\ University of Manchester \\ Manchester \\ M13 9PL \\ United Kingdom. \\ Email: \\ dmitrijs.andrejevs@postgrad.manchester.ac.uk
}

This is the author accepted manuscript (Version 2).

The paper is expected to be published in Memory Studies in 2018 (OnlineFirst) and in the 14.2 April 2021 issue. 
Revisiting the social organisation of national memory: a look at the calendars of Lithuania, Latvia, and Estonia. ${ }^{1}$

\section{Abstract}

This article presents a study of the social organisation of the national memories of Lithuania, Latvia, and Estonia (the Baltic states). It draws inspiration from and expands the scope of the application of Eviatar Zerubavel's largely unexplored methodological tools for the study of calendars. Accordingly, the purpose of this paper is threefold. First, this paper offers an application of the above tools to the case of the Baltic states. Second, by doing so it provides an overview of comparative patterns within Baltic calendars. Third, it is argued that by exposing the social organisation of national memory, this approach offers insight into silences, providing an entry point for an engagement with amnesiology, as coined by Liedeke Plate.

\section{Key words}

Baltic states, calendar, national commemogram, national memory, silence 
Recovered memories have been central to the post-Soviet transformations in the Baltic states. Public commemoration was instrumental within this process in the late-1980s and early-1990s. Specifically, under the auspices of the reforms launched in the Soviet Union in the mid-1980s, public commemorations known as 'calendar demonstrations' (Lieven, 1994: 221) proliferated during this period. By the late-1980s these demonstrations gave rise to 'the counter-calendar', challenging the official Soviet calendrical holidays by marking prominent anniversaries of the interwar period as well as anniversaries of more traumatic events of the late-1930s and 1940s, such as the deportations of 1941 (Lieven, 1994: 221; Plakans, 2011: 390-391).

Despite the institutionalisation of the counter-calendars in the 1990s, comparative studies remain scarce within the field of Baltic Studies (e.g. O'Connor, 2006: 91-100; Eglitis and Ardava, 2014; Pettai and Pettai, 2015: 224-236). Instead, scholars tend to focus on a single country, either by taking a top-down approach or devoting attention to the bottom-up reception of said calendars (e.g. Kuznecovienè, 2008; Zepa et al, 2008; Tamm, 2013; Kõiva, 2013; Korolova et al, 2015; Senvaitytè, 2015). Within this corpus of literature, analyses under the auspices of memory studies are just one piece of the disciplinary puzzle in the study of Baltic calendars. 
Within memory studies at large, Eviatar Zerubavel's (2003, 2004a) chapter 'Calendars and History: A Comparative Study of the Social Organization of National Memory' as well as his later book Time Maps have intuitive appeal. Indeed, many papers that deal with calendrical matters, including entries that appeared in Memory Studies (David, 2014; Fridman, 2015), often reference these two titles. Despite that, scholars tend not to touch upon or merely refer to his methodological tools, even though they could help us to better navigate 'a sociomental topography of the past' (Zerubavel, 2004a: 1; e.g. Cossu, 2010: 16).

Accordingly, the purpose of this paper is threefold. First, this paper uses the calendars of the Baltic states to illustrate an application of Zerubavel's mnemonic tools commemograms/cardiograms. Second, by doing so it aims to contribute to a comparative understanding of the mnemonic patterns within these calendars. At the same time, the presented study is not envisioned as an exhaustive treatment of comparative patterns, and the interest remains with commonality rather than difference throughout. Within this agenda, the paper is interested in the calendars of Lithuania, Latvia, and Estonia as of 2016/2017, seeking to provide insight into the social organisation of national memory within them (Zerubavel, 2003). 
Every national calendar can be understood as consisting of marked and unmarked days. This paper recognises that marked days often operate within a hierarchical system (for example, the division between national holidays and commemorative days). The interest here, however, is in the joint primary function of the marked days, rather than the relationship between them. In other words, this paper focuses on the fact that marked days are 'specifically designed to commemorate "sacred" historical events' (Zerubavel, 2004b: 191). Eviatar Zerubavel (2003: 316; cf. Nora, 1989) even eloquently refers to the calendar as 'perhaps the most spectacular site of collective memory'.

By prescribing what we ought to remember as well as when to remember, the calendar takes part in the process of 'mnemonic socialization', at the very least theoretically, sustaining and transferring the content of collective memory (Zerubavel, 2004a: 47; cf. Etzioni, 2004). Within this process, mnemonic attention is focused on some parts of nation's history, while others are cast into irrelevance (Zerubavel, 1996: 286). Given this observation, this paper will conclude by pointing towards silences within Baltic calendars 'spaces either beyond words or conventionally delimited as left out of what we talk about' (Winter, 2010: 4; cf. Vinitzky-Seroussi and Teeger, 2010). In this respect, this paper aims to 
contribute to the agenda of amnesiology, as recently proposed by Liedeke Plate (2016: 148) on the pages of this journal.

The central elements of the social organisation of national memory, or collective memory, 'are parts of everyday speech, and as such lose any concrete meaning they may once have had', as Jay Winter (2010: 11-12) asserts. Accordingly, to define the parameters of national memory and build a foundation for analysis, the rest of the paper will proceed as follows. The first part of this article will outline conceptual contours and the structure of national memory, drawing on the works of Aleida Assmann and Eviatar Zerubavel. These sections will be followed by an outline of methodological assumptions and a modified application of Zerubavel's mnemonic cardiograms and national commemograms to the case of the Baltic states. The last section will address the main silences within Baltic calendars, providing an illustration of how Zerubavel's mnemonic tools can provide an entry point into amnesiology (Plate, 2016).

\section{Contours of national memory}

Eviatar Zerubavel's (2003: 319, emphasis in the original) approach to national memory within calendars was driven by his interest in the nation(-state), confining him to national calendars and more specifically 'national commemorative holidays'. Moreover, his 
approach was conditioned by a focus on the structure of national memory. Its conceptual contours are only of secondary concern: in the end, the structural approach presupposes similarities across formats, as per below. To expand the latter understanding and to further supplement the structural conception of national memory, this paper draws on the work of Aleida Assmann (2008: 55), who suggests treating 'collective memory' as an 'umbrella term for different formats of memory that need to be further distinguished'. While Assmann (2004; cf. 2008: 55) speaks of four formats (individual, social, political, and cultural), the main interest of this paper is with the political-national format of memory (hereafter national memory) - institutionalised and official memory. Institutionalisation allows national memory to be extended in space and time, lending it a degree of durability as well as transgenerational character (Assmann, 2004: 25, 2016: 11).

In turn, national memory is mediated and requires durable carriers - it depends on the support of and in turn existence of governments and institutions to underline it (Assmann, 2004: 35 , 2008: 55-56). Specifically, this paper is interested in calendars as products of this process, as 'institutionalized occasions for remembering' (Zerubavel, 2003: 317). Theoretically, it is recognised that institutionalisation implies that calendars might 'run to the end of time' (Zerubavel 2003: 317). Empirically, however, it is expected that their 
prominence and associated meaning(s) will remain subject to variation, change and devaluation (e.g. Cressy, 1996; Spillman, 1998; Schwartz, 2008). These changes, however, are not of prime interest to this paper.

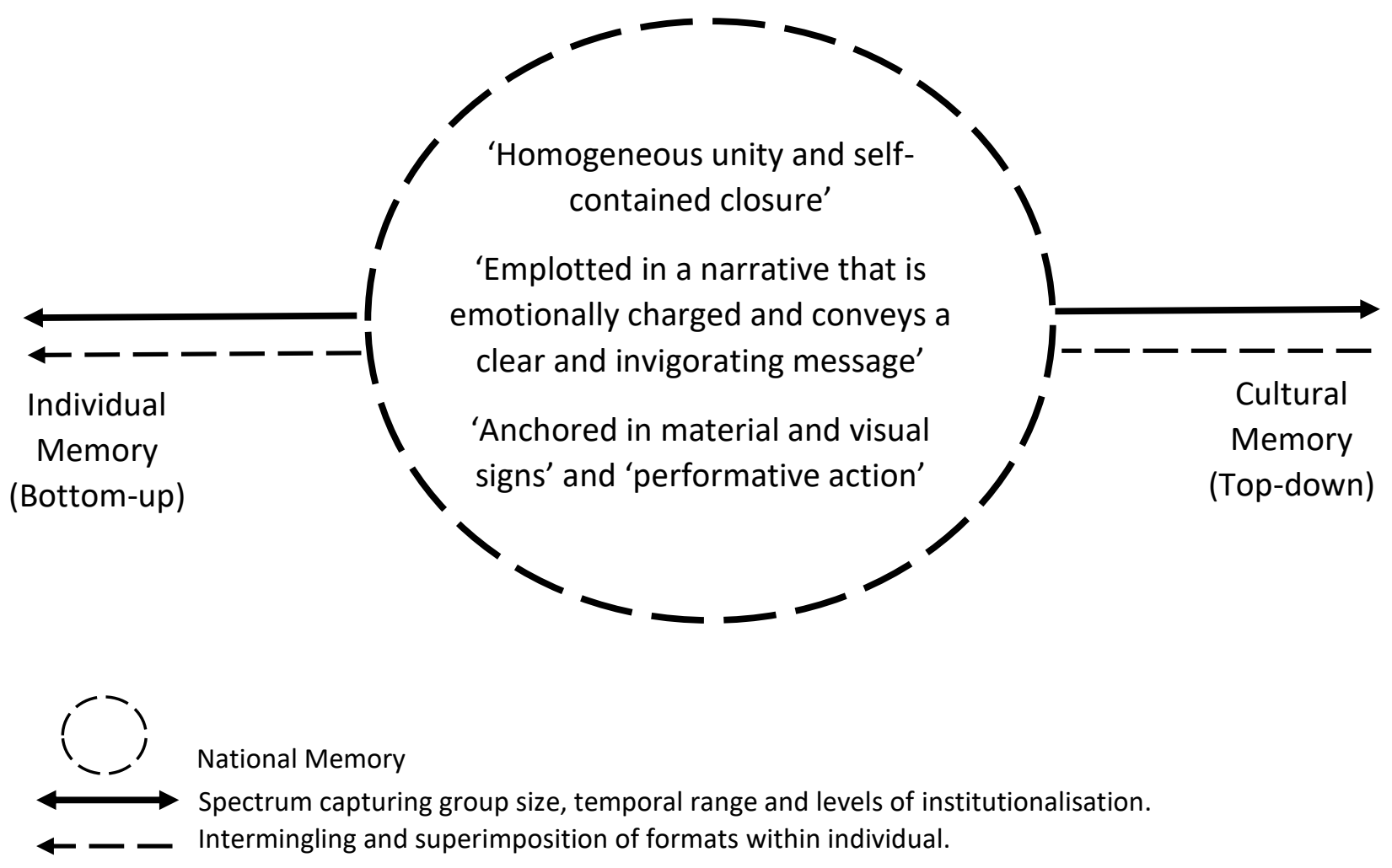

Figure 1. Contours of national memory (Source: compiled by the author, based on Assmann, 2004:

25-26; and Assmann, 2016: 11). 
Importantly, Assmann (2004: 26; see Figure 1) suggests differentiating features of national memory, which this paper considers as its conceptual contours, helping to navigate nonstructural grounds. In other words, 'we can speak of a political or a national memory when history is put to the service of identity formation, when it is appropriated by citizens and attested to by politicians' (Assmann, 2016: 23). Accordingly, national memory ends up working as a "'matrix of meaning" for nationally conscious individuals' (Müller cited in Onken, 2010: 280; see Figure 1).

\section{Structure of national memory}

In this respect, institutionalisation commits the national past to the annual calendrical cycle, which becomes a carrier of national memory (Zerubavel, 2003: 332). The structure of a national collective past within national memory is represented by 'commemorative density' or 'mnemonic density' that points towards what national memory magnifies to assign it significance (Zerubavel, 1995: 8, emphasis in the original; Zerubavel, 2003: 315; Zerubavel,

2004a: 26, emphasis in the original). Similarly, the calendar operates within the realm of 'commemorative time', rather than metric historical time, creating an uneven national timeline within which a few compact and yet highly momentous episodes take prominence, while others are compressed 'to near-oblivion' (Zerubavel, 1995: 9, emphasis in the original; 
Zerubavel, 2004b: 189). These compressed periods become silent witnesses of commemorative elevation of their historic counterparts; their 'monumental' punctuation of historic time (cf. Assmann cited in Casquete, 2013: 27).

At the same time, calendrical temporal monumentality remains symbolic - after all, calendars do not 'literally embody the actual temporal profiles of the historical events' (Zerubavel, 2003: 332). Nevertheless, drawing on the work of Liron Lavi (2013: 702), calendars play a role in 'Chrono-Work' that sustains national identity by assisting in assembling selected commemorative anchors into a chronological continuum. In other words, national days and calendars at large are the 'key markers in national biography' alongside which national narrative is constructed (McCrone and McPherson 2009: 213). The structural distribution of such markers implies that calendars 'embody tacit cardiogramand seismogram-like narratives that encapsulate nations' collective histories', providing an insight into identities of mnemonic communities (Zerubavel, 2003: 326, 319; cf. Tamm, 2008 on narrative community).

\section{Visualising national memory: mnemonic cardiograms and commemograms}

The structure and homogeneity of national memory invite a systemic analysis. Eviatar Zerubavel (2003) speaks of the 'national commemogram' that can assist us in conducting 
such a study. In his writings, commemograms are presented on two occasions (Zerubavel, 2003: 327, 329; 2004a: 32). In constructing them, Zerubavel (2003: 326) draws inspiration from seismograms and cardiograms which are transformed for the needs of mnemonic nature. Indeed, 'national commemogram' and 'mnemonic cardiogram' become synonymous, capturing the structure of national memory. For practical reasons, this paper makes a slight distinction based on the visual appearance of the two: first, 'national commemogram' (to be read in this case as a 'commemorative programme or timeline') and second 'mnemonic cardiogram' (as per metaphor).

The two represent the methodological tools that allow us to move from a theoretical to an empirical analysis (Zerubavel, 2004b: 189). In other words, it is the process of creating mnemonic timelines by tracing chronological distribution of events within national memory that allows the capturing of its structure (Zerubavel, 2004b: 189). In turn, interest is not with what happened, but rather with history as and how it is remembered (Zerubavel, 2004a: 2; also see Tamm, 2008). To achieve this, two ideas within semiotics become instrumental, differentiation and markedness: the process of differentiation between marked and unmarked history 'allows us to assign the former any social significance' (Zerubavel, 2004b: 184-185, 191-192, emphasis in the original). 
While the focus of this paper remains with national memory, it is worth acknowledging that 'the actual meanings engaged, digested, ignored, or rejected cannot simply be inferred from the nominally national properties of the holidays themselves' (Fox, 2006: 221). Consequently, this paper does not claim to offer answers to the reception of national calendars in the Baltic states. Equally, while this paper is inspired by Zerubavel's (2003: 320) detached and synchronic pattern analysis, it relaxes the de-contextual demands of the original framework to accommodate interest in 'nation-specific mnemonic idiosyncrasies'. Similarly, while Zerubavel's (2003: 319) approach is confined to public holidays, this paper extends the scope by including commemorative/remembrance/ memorial days (treated as synonymous in this paper).

\section{Past to be remembered: the social organisation of Baltic national memories}

To present an application of the methodological tools outlined above this paper consulted institutionalised (law stipulated) calendars of Lithuania, Latvia and Estonia. To accommodate the focus of this paper and in a slight deviation from Zerubavel $(2003)^{2}$, only days marking a historical event or a historical period in any of the three nations' histories were considered in this work, while religious and most international and professional days were excluded. The calendars were compiled from sources available online (see 
Appendices). Online as well as printed materials such as historical dictionaries and reference books were used to ascertain historical event or period behind calendrical days (e.g. Skangale, 2011) ${ }^{3}$.

Based on the material reviewed, when it comes to mnemonic density, the Lithuanian calendar by far exceeds that of Latvia or Estonia (see Figure 2). There are two primary reasons behind this. Firstly, it is the result of 'the time depth of "national" history invoked' (Lentz, 2013: 214). In other words, by referencing the $13^{\text {th }}$ century and Grand Duchy of Lithuania, their calendar creates a distinct depth and density of national timeline that cannot be claimed by Latvia or Estonia (see Figure 2). Secondly, less binding memorial days are the primary contributors to the Lithuanian density (holidays denoted by upper $\mathrm{H}$ in the Appendices). Bracketing the questions of hierarchy, many of the days within the Lithuanian calendar do not require raising of the flag or presuppose any extensive public commemoration. Thus, while still bearing mnemonic weight, the non-interruptive nature of such commemorative days to everyday life allows the Lithuanian calendar to exhibit a much greater density compared to the Latvian and Estonian calendars (see E-tar.It, 2016). Within national commemograms themselves (see Appendices), while the general tendency towards synchronisation of calendrical and historical time is observed, a few instances of 
'symbolic compression' are equally evident in the cases of the Lithuanian and Latvian calendars, which dedicate days to specific periods rather than singular events (Zerubavel, 2003: 333).

(a) Lithuanian mnemonic cardiogram

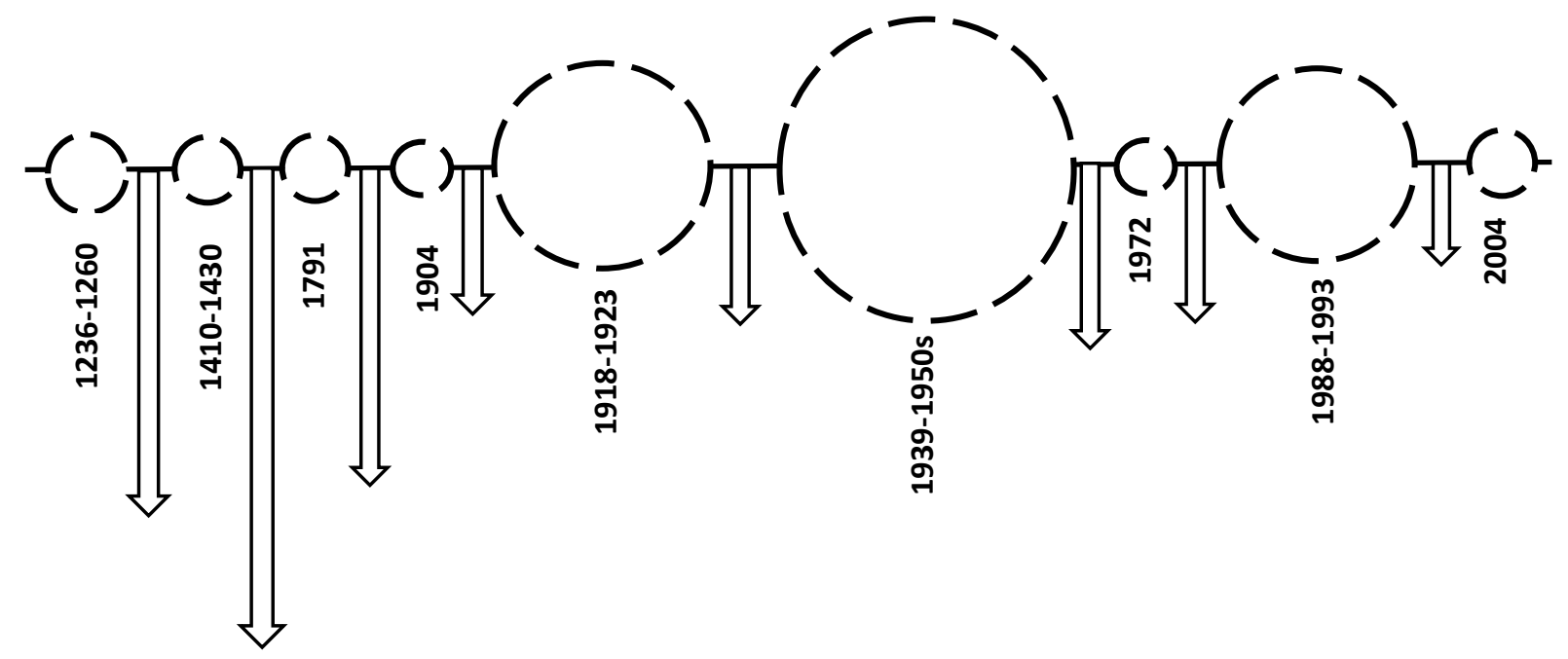

(b) Latvian mnemonic cardiogram

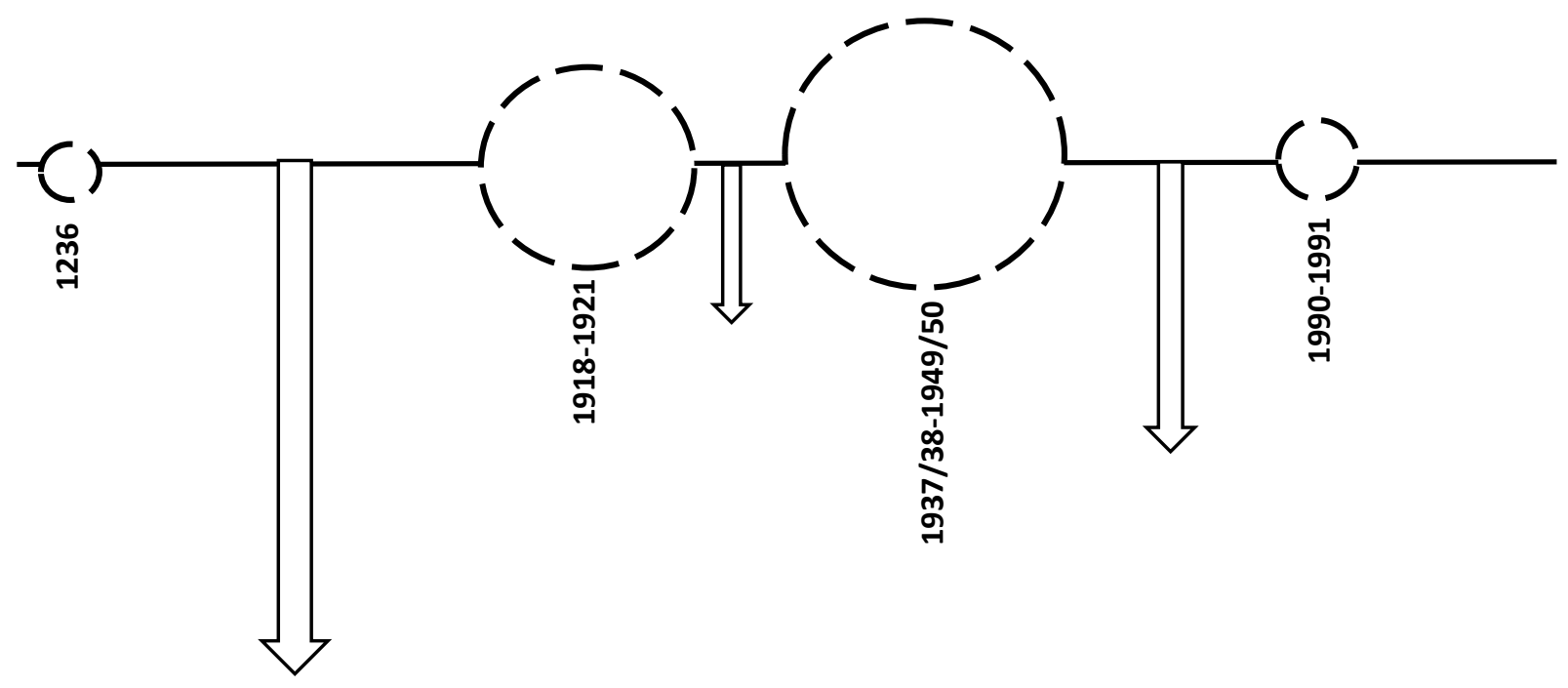




\section{(c) Estonian mnemonic cardiogram}
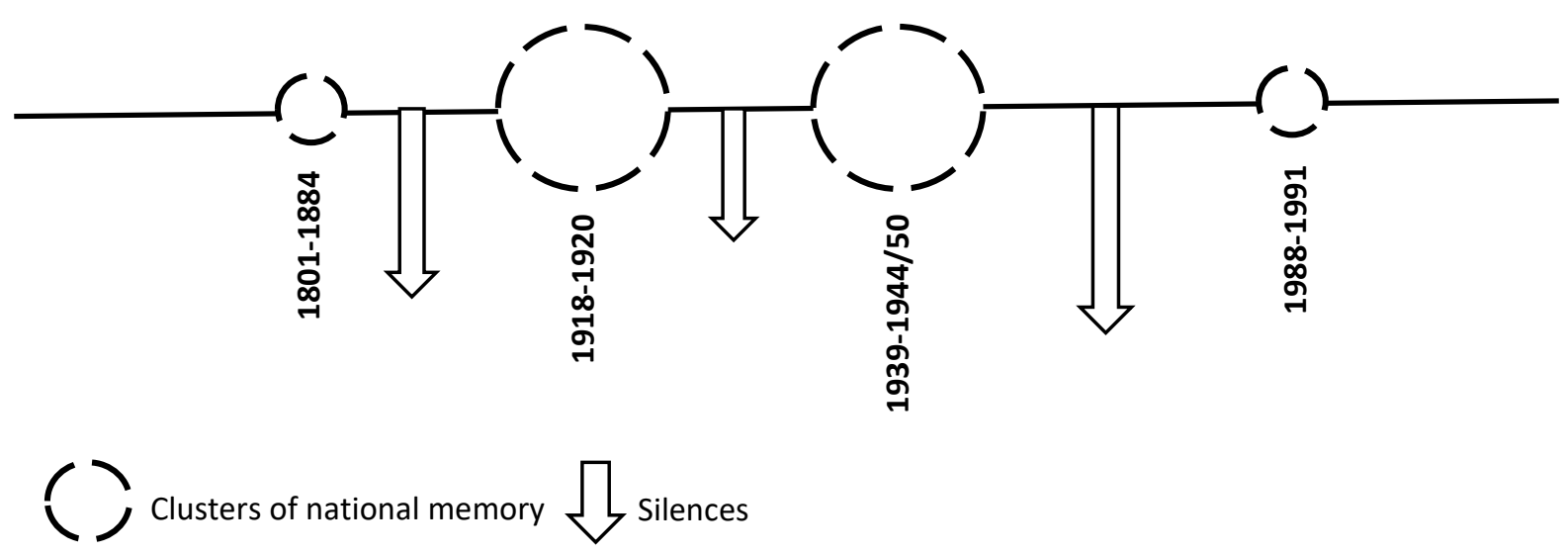

Figure 2. Mnemonic cardiograms of Lithuania, Latvia, and Estonia (Source: compiled by the author, based on Appendices).

The compressed calendrical markers relate to the more traumatic events in Lithuanian and Latvian history and specifically encompass the actions of the Soviet regime at the onset or around the Second World War (i.e. 1937-1938; 1944-1947 and the early-1950s, see Appendix $A(b)$ and $B(a))$.

The incorporation of the Baltic states into the Soviet Union at the time of the Second World War, and a degree of overlap in the larger national development of the countries, assist in the establishment of the observances by 'mnemonic communities that are larger than the 
nation-state' (Zerubavel, 2003: 331). The two most prominent examples ${ }^{4}$ in recent years are 23 August and 9 May, commemorating signing of the Molotov-Ribbentrop Pact/Baltic Way, and the Schuman Declaration, respectively. Their prominence has arguably been driven, first and foremost, by their transnational significance.

In this respect, a tension of meaning can be observed with regards to 9 May in the Baltic states, that of 'Europe Day' and 'Victory Day' (for example, in Russia). The two mark not only different temporalities (Soviet and European/post-Soviet) but equally different mnemonic orientations within contemporary Europe (that is, of the West and East). It is in this regard, for instance, that the Latvian calendar underwent its first 'seemingly small, and yet significant' amendment in 1995 (Pettai and Pettai, 2015: 232). The Remembrance Day dedicated to the end of the Second World War was shifted from its Soviet/Russian anchor on 9 May to a Western European 8 May, signalling mnemonic reorientation and performativity of 'Europeanness' (cf. Pettai and Pettai, 2015: 232) ${ }^{5}$. On a symbolic level, 9 May in the Baltic states is now assigned the meaning of 'Europe Day' and can be located within the Baltic narrative of the traumatic interruption of their European development in the early twentieth century and their final return to Europe in 2004. 
At the same time, the Baltic (and East European at large) return to Europe has prompted a recent reassessment of the common European remembrance framework. Within this process, the Baltic states were at the forefront of integrating their communist experiences into European understanding of the ramifications of the Second World War, thus in part claiming their newly recovered 'Europeanness' (Onken, 2007; Mälksoo, 2009). Importantly, this mnemonic activism resulted in the elevation of the date of signing of the MolotovRibbentrop Pact (23 August) to the pan-European level via the institutionalisation of the 'European Day of Remembrance for Victims of Stalinism and Nazism', simultaneously making its way into national calendars of Latvia and Estonia in 2009 (cf. e.g. Mälksoo, 2014). This emphasis on the duality of totalitarianism in the twentieth century (that is, Soviet/Communist and Nazi German/Fascist) equally comes to the fore in the social organisation of Baltic national memories. Overall, however, the commemorative timeline presents several major clusters in all three Baltic countries. The pre-twentieth century clusters are scattered and deflated in comparison to other periods in all three countries, marking national 'beginnings'. In that way, the 'Day of Baltic Unity' (1236) in Latvia and Lithuania, according to the presidents of the two countries, prescribes 'to remember our roots, the rich cultures of our two nations, our shared history, and fights for freedom' 
(Zatlers and Adamkus, 2007). In Lithuania, the above day is followed by the 'Statehood Day (Lithuanian King Mindaugas Coronation Day)' (1253) that essentially delineates the origins of Lithuanian nationhood. Estonia's chronological starting point is marked with the 'Native Language Day' on 14 March (1801), dedicated to the birthday of Kristjan Jaak Peterson. At the time of German dominance at the University of Tartu, Peterson's acknowledgement of his Estonian origin as well as his 'amazingly modern' for the time poetry, in later years earned him the inscription among the 'forefathers' of Estonian poetry and as a developer of Estonian language (Taagepera, 1993: 29). Kristjan Peterson's birthday is followed by 'National Flag Day', marking the declaration of the flag as that of the Estonian Students' Society (Eesti Üliõpilaste Selts) in 1884. It provides a more concrete token of national statehood, and the symbolism of the place that unites them - the University of Tartu - lends a link between the two days.

The explicit 'personification' of memory through the wording of holidays or commemorative days, however, remains rather nominal in the Baltics and largely reflects the canon of heroes. In the case of Lithuania, Grand Dukes Mindaugas and Vytautas distinguish themselves most prominently, underlining their enduring place within the canon and the assigned role of 'founding fathers' (see Appendix A(a); cf. Šutinienè, 2009). In Latvia, 
the main example is embodied within Lāčplēsis Day (11 November), alluding to the Latvian folklore hero, Lāčplēsis (Bearslayer), and thereby transforming a mere literary hero into a national one by endowing him with a historic life outside the immediate pages of the literary epic (cf. Cimdina, 2010). Unsurprisingly, the above introduced commemorated figures also find monumental embodiments in both countries, solidifying their heroic position. Prominently, Lāčplēsis is immortalised on the interwar built 'Freedom Monument' in Riga; the monument to 'King Mindaugas' is placed outside the National Museum of Lithuania in Vilnius, with the monument to Vytautas to be found in Kaunas. Just a short distance away in the same city, another monument is dedicated to Romas Kalanta, who committed an act of self-immolation in protest against Soviet occupation on 14 May (1972). The day, despite being institutionalised as 'Civil Resistance Day', promotes 'oneness', elevating Romas Kalanta's act above all other individual instances of resistance during the Soviet period (cf. Schwartz, 2009). The contestation of this 'oneness' and the context of his death, however, work against univocal inscription into a canon of heroes, as Amanda Swain's (2012) study of parliamentary (Seimas) debates illustrates.

When it comes to the twentieth century, the calendars become more 'synchronised' with three distinct clusters observable in all three calendars, indicating a tendency towards 
'Baltic Memory' (Kõresaar, 2016: 431; see Figure 2). The first twentieth-century cluster captures the period of the Wars of Independence and early parliamentary years $(\approx 1918$ early 1920s), marking the beginning of Baltic statehood and underlying their democratic credentials. However, while statehood for Latvia and Estonia was indeed 'new', Lithuania, through the wording of the public holiday, appeals to the earlier recorded instances of medieval and early modern statehood. As a result, three main commemorative anchors, instead of the equivalent two in the cases of Latvia and Estonia, bracket the Lithuanian nation-state(hood): 6 July (1253), 16 February (1918) and 11 March (1990). According to the website dedicated to the centenary of independence ('Restored Lithuania $\left.100^{\prime}\right)^{6}$, 'this date [16 February 1918] is like a bridge between the old Lithuania born on 6 July 1253 and the new independent Lithuania restored on 11 March 1990' (lietuva.It, 2017). Interestingly, the Wars of Independence are marked explicitly in Latvia and Estonia, but not in Lithuania where the mnemonic focus seems to have been shifted to the medieval and post-Second World War independence struggles.

The second mnemonically dense cluster of national memory is dedicated to the Soviet and Nazi German occupations ( $\approx$ 1939/40-early 1950s). The Soviet occupation dominates and sets the tone of the entire cluster, as will be discussed in more detail in the next section. 
The third prominent cluster relates to the period of 'Singing Revolution' that led to the restoration of independence in the early 1990s ( $\approx$ late 1980s-early 1990s). This period gave the greatest impetus to the creation of the anti-Soviet resistance narrative that was one of the main pillars of post-independence nation-building. The above two clusters worked in tandem, providing legitimacy to the disassociation from the Soviet period. In that way, within the social organisation of national memory - and within twentieth-century memory specifically - occupation(s) and independence become two main organising principles.

\section{Silences within the social organisation of national memory}

By exposing the shapes of national memory, the suggested approach utilising 'mnemonic cardiograms/commemograms' not only provides insights into the dynamics of remembrance, but it equally allows for a study of silent parts revealed on the drawn mnemonic timelines. The preceding discussion established a pattern of three main mnemonic clusters in all three countries. At the same time, looking at their organisation (see Figure 2 and Figure 3), two prominent 'calendro-commemorative gaps' become apparent (Zerubavel, 2003: 329-330; Winter, 2010: 20).

The mnemonic cluster of 'independence' establishes itself on the background of the nineteenth century silence, during which the Baltic states were part of the Russian Empire. 
This absence enforces the message of denial of 'the full realization of their legitimacy as separate political entities', elevating the tipping point of 1918 independence proclamations (Zerubavel, 1995: 8). Even when references are made to the imperial period (for example, 7 May 1904 in Lithuania) emphasis seems to be on the struggle for freedom and National Awakening(s) that find their climax in the (re-)establishment of the independent state. At the same time, while a 'sudden beginning' in 1918 and an 'abrupt end' in the 1940s is remembered in the Baltic states, an authoritarian 'mid-term crisis' of the late 1920s -1930s proves to be too controversial for a univocal inscription into national memory, resulting in a mnemonic split of the independence period (see Figure 3; Hope, 1996: 41). Similarly, the relative stability of these regimes works against an easy commemorative inscription in comparison to the turbulent years of 1918 to the 1920 s. However, while absent within calendars ${ }^{7}$, this period finds representation in other formats of memory.

In Latvia for instance, the Ulmaṇlaiki period, during which the late Kārlis Ulmanis headed an authoritarian government, remains among the most positively viewed in the country's twentieth century history (Kaprāns and Saulītis, 2017: 9-16). The often-mythologised appropriation of this period within social memory works in tandem with the national 
memory, establishing an assimilated independence period (see Figure 3(a); cf. Boldāne 2006).

The collapse of the authoritarian regimes in the Baltic states opened the stage for an emphasis on 'two' or even 'three' occupations (Soviet to Nazi German to Soviet), underlined by the notion of 'double genocide' (more prominently in Lithuania and Latvia; see Appendix $A(b)$ and $B)$. The afore mentioned institutionalisation of the 'European Day of Remembrance for Victims of Stalinism and Nazism' is, in turn, a reflection of the Baltic attempts at drawing equality between the two regimes. At the same time, despite their quest for demonstrating 'Europeanness' by expanding the mnemonic space, the commemorative density of Soviet occupation(s) tends to overshadow the singular commemorative date dedicated to the Holocaust (see Appendices; cf. Himka and Michlic, 2013) ${ }^{8}$. However, precisely this mnemonic focus, relying on the 'myth of victimhood and cult of authenticity', provided the base on which newly independent Baltic states could anchor their identity (Hackmann and Lehti, 2012). To this day it largely remains in place.

Within this base, the Soviet period of the 1940s is inflated and the late-Soviet period is cast into irrelevance, apart from the late 1980s, early 1990s, and 1972 in Lithuania, that themselves belong to the categories of martyrology and resistance ${ }^{9}$. This patterning or 
periodisation of historical time can be interpreted through the prism of a strategic silence a tool of political persuasion- as Ketil Knutsen (2016: 126) puts it.

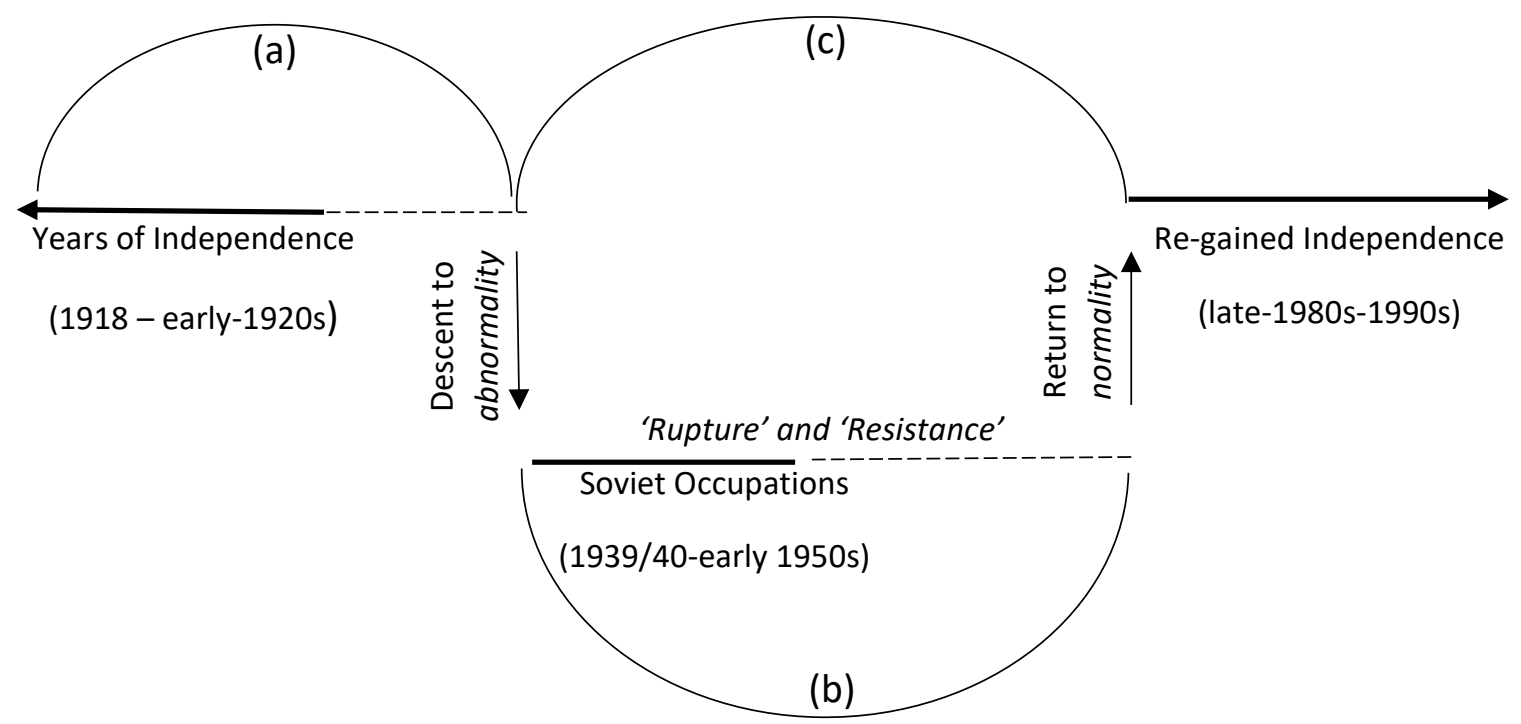

(a) Independence period assimilation (b) Soviet period assimilation (c) Normality/rupture bridge Marked periods - - - - - Calendro-commemorative gaps

Figure 3. Connections between marked and unmarked periods (Source: compiled by the author).

In this respect, the lack of over 40 years of history in the national memory is a purposive mnemonic decision, resulting in the entire Soviet period being assigned a Stalinist identity (see Figure 3(b)). The assimilated Soviet period becomes emplotted in the narrative of 
decline, imposing a specific temporal order on the flow of history (see Figure 3; cf. Zerubavel, 2004a: 16-18). It is presented as alien and interruptive of the 'normal' national progression (see Figure 3(c)). In the words of the current Lithuanian president, Dalia Grybauskaitè (2016), 'five long decades were ripped away from the one hundred years of our journey by the Soviet occupation which left us with many unhealing wounds'. In turn, within this temporal order, the Soviet occupation becomes a 'filter of meaning', operationalised through the lenses of 'rupture' and 'resistance' as illustrated by Estonian presidential speeches on a national holiday, 24 February (see Jõesalu, 2012; Jõesalu and Kõresaar, 2013: 177; Figure 3). With the whole Soviet period being represented as equally alien, the intra-Soviet differences become trivial. By the same token, the late-Soviet period falls under the mnemonic blade and is 'mnemocided' from national memory, transforming into a Red 'Elephant in the Room' (Zerubavel, 2010; Assmann, 2015: 26). The emphasis on rupture and decline, however, presupposes a point in time that serves as an anchor of normality.

In this respect, since the whole period from the late 1940s up to 1991 is interpreted through the prism of 'rupture' and 'resistance', it allowed for the (re-)imagining and (re)constructing of the post-1991 republics as a continuation of early twentieth century 
statehood, providing a symbolic link to the 'temporal normality' of the interwar period (Eglitis, 2002: 17, emphasis in the original; see Figure 3(c)). As was the case with other postcommunist states that could claim such continuity, the return of some of the pre-Second World War calendrical days in the Baltic states helped to solidify such symbolical temporal continuity (for example, Poland; Ochman, 2013: 27-29). Most prominently, the proclamation of independence in 1918 was drawn upon when creating calendrical continuity. Marek Tamm (2013: 662) even observed that the decision surrounding the 'upgrading' of 20 August (1991) within the Estonian calendar in the 1990s was veiled in its perceived conflict with the above date of 24 February (1918). The Estonian parliament (Riigikogu) voiced concerns that the elevation of 20 August to a public holiday 'would undermine the significance of 24 February and endanger the idea of legal continuity' (Tamm, 2013: 662). While the two days coexist in the contemporary realm of public holidays in all three countries, the above considerations of the Estonian parliament underline EvaClarita Onken's (2007: 38) observation that since regaining independence, the idea of continuity of statehood has been 'the central historical notion for Estonians, Latvians and Lithuanians'. Nevertheless, leaving the legal underpinnings of said continuity aside, the 
preceding discussion illustrates that this notion is emphasized by the created commemorative time rather than metric historical time.

At the same time, Winter (2010: 23) points out that silences have temporal expiry dates in line with the needs of the time in which they are imbedded. In a similar spirit, Kirsti Jõesalu and Ene Kõresaar (2013: 196) observe that in more recent years in Estonia 'the negative discourse of rupture and the positive discourse that emphasizes the continuity of everyday experiences have found ways of co-existing'. Similarly, Mārtiņš Kaprāns (2016: 102) argued that while the preservation of the anti-Soviet narrative in Latvia retains its place as 'a pivotal legitimating historical force', it conversely coexists with the 'alternative and emancipated discourses'. Thus, while memory of the late-Soviet period is silenced within national memory, it nevertheless finds a 'voice' within other formats of memory and through mediums such as 'life writing', theatre and newspapers (also see Onken, 2010; Kõresaar, 2016).

At the same time the hierarchisation of memory implies that these memories co-exist on different ontological levels; with the public level being assigned to the normative mnemonic framework of the national memory, and the heterogeneity of memories being contained within the social level (cf. Assmann, 2016: 171-173). In other words, 'emancipated' 
memories do not challenge the established normative framework as most of the time they do not reach the level of national memory (cf. Onken, 2010). In a similar spirit, Jõesalu and Kõresaar (2013: 196) note that the identified discourses of 'rupture' and 'continuity/normality' as applied to the late-Soviet period 'describe the Soviet experience in different social spheres' (that is, public versus private). In this respect, as illustrated by all Baltic calendars, national memory retains its characteristic homogeneous and selfcontained contours and remains an established normative scheme. The dynamics on the social level, however, have the potential to loosen the grip of national memory (cf. Safronovas, 2014). Social dynamics, however, fall outside the remit of this paper.

\section{Concluding remarks}

Over the years many scholars have drawn inspiration from Eviatar Zerubavel's writings on calendars. Concurrently, his methodological tools have remained largely untouched. In contrast to earlier scholarly work, this paper draws inspiration from Zerubavel's methodological tools in the study of the social organisation of national memory mnemonic cardiograms/commemograms. It was argued that Zerubavel's approach could be supplemented by the writings of Aleida Assmann and expanded in scope by including commemorative days. In turn, Assmann's work helps to establish guiding conceptual 
contours of national memory. In this respect, it provides a complimentary function to Zerubavel's more structurally orientated understating of this format of memory.

In terms of the Baltic social organisation of national memory, two organising motifs, namely occupation(s) and independence, have been suggested. In this respect, a pattern of three mnemonic clusters is observed in all three calendars: periods of independence $(\approx 1918$-early 1920 s), occupations ( $\approx 1939 / 40$-early 1950 s) and re-gained independence ( $\approx$ late 1980 searly 1990s). By studying the organisation of these clusters in relation to one another, two prominent calendro-commemorative gaps become visible - that provide an entry point into engagement with amnesiology (Plate, 2016). This paper paid closer attention to the strategic silencing of Soviet times within national memory ( $\approx 1950$ s-1980s), which provides coherence and meaning to the post-1990s states, by, in part, allowing to make an emphasis on continuity of statehood (1918 to $1990 / 91)$. At the same time, while the focus remained on national memory, it was noted that this silencing of the late-Soviet period tends to break down within other formats of memory, namely individual, social, and cultural. Nevertheless, these memories co-exist with the imperatives of national memory, which retains its homogeneity. 
This paper was interested in the structural and strategic nature of the Baltic states' calendrical-history. While the presented analysis relaxed the de-contextual assumption of Zerubavel's approach, it retained its synchronic focus for the most part. Thus, asynchronous comparative work is required to shed further light on the Baltic calendars, taking into account their evolution, restoration, and the impact of domestic as well as international forces upon these processes. The focus on the shapes and patterns of national memory equally resulted in an aggregate treatment of comparative dynamics as well as silences within national timelines. While it provides us with a structural overview, further engagement with silences is warranted to develop a deeper understanding of these periods in the Baltic states. The presented structural skeleton of national memories could provide a guiding framework for further and closer explorations of both what is said and what is cast into irrelevance.

\section{Acknowledgments}

This paper builds upon my honours dissertation at the University of Aberdeen, that was awarded the prize for the Best Politics Dissertation in 2016. I would like to extend my gratitude to Nataliya Danilova for her supervision and the comments on the draft of this article. Equally, I would like to thank Anna Rabea Schwarzmann, Erika Harris, Ewa Ochman 
and two anonymous reviewers for their valuable suggestions. The gratitude is extended to Maksim Safonov for taking a kind look at the translations from Lithuanian.

\section{Conflict of Interest}

The author(s) declared no potential conflicts of interest with respect to the research, authorship, and/or publication of this article.

\section{Funding}

The author(s) received no financial support for the research, authorship, and/or publication of this article.

\section{Notes}

1. The title of this paper alludes to Eviatar Zerubavel's (2003) chapter, 'Calendars and History: A Comparative Study of the Social Organization of National Memory'.

2. If religious holidays were to be included in the scope of this article, a similar 'bipolar' structure noted by Zerubavel (2003: 326-327) consisting of a 'distant' religious past and politically significant anchors of the recent centuries could be expected. 
3. The translations of Latvian and Lithuanian calendars were done by the author. The author, however, is fluent in Latvian, but not in Lithuanian or Estonian. In turn, the scope of the material is in part reflective of the author's linguistic abilities.

4. Other examples include: 22 September (Lithuania; Latvia); 14 June (Lithuania; Latvia; Estonia); 8 May (Lithuania; Latvia; Estonia); 22-23 June (Latvia; Estonia) and 13/20 January (Lithuania; Latvia, respectively).

5. (International) Day of Remembrance for the Victims of the Second World War is not legally stipulated in Estonia, but is observed on 8 May (see Pettai and Pettai, 2015: 235). The 8/9 May tension, more prominently so in Latvia and Estonia, equally reflects the multiplicity of mnemonic communities within the countries (for example, Latvian and Russian-speaking; see, e.g. Ločmele et al, 2011; Kaprāns and Saulītis, 2017: 50-56).

6. In Lithuania, the centenary commemoration spans four years from 2017 to 2020 (see http://www.lietuva.It/100/en/, accessed 5 July 2017). In a similar spirit, the Latvian centenary programme is planned to span five years (2017-2021) (see http://lv100.Iv/en/programme/, accessed 5 July 2017). In Estonia, the celebration programme will span four years (2017-2020) (see https://www.ev100.ee/en/commemorative-events, accessed 5 July 2017). At this point, it 
is worth noting the close resemblance of commemorative anchors within centenary programmes and the calendars.

7. The period finds an indirect representation through the limited reinstatement of the 'authoritarian period' instituted calendrical days, prominently 'Victory Day' in Estonia (see Brüggemann, 2015).

8. (International) Holocaust Remembrance Day is not legally stipulated in Estonia, but since 2003 it has been marked on 27 January (see Tamm, 2013: 665).

9. In terms of calendars, the question, however, would be that of finding a meaningful commemorative-anniversary anchor for the mid-term Soviet period. After all, arguably, even the Soviet regime had difficulties in finding such anchors. On Soviet calendars in the Baltics, see e.g. Zelče, 2004; Kreegipuu, 2011; Senvaitytè, 2015. 


\section{Appendices}

(a)

\begin{tabular}{|c|c|}
\hline Day of Baltic Unity & 22 September 1236 \\
\hline $\begin{array}{c}\text { Statehood Day (Lithuanian King Mindaugas Coronation Day) } \\
\text { The Day of the Battle of Durbe }\end{array}$ & $\begin{array}{l}6 \text { July } 1253 \\
13 \text { July } 1260\end{array}$ \\
\hline $\begin{array}{l}\text { The Day of the Battle of Grunwald (Žalgiris) } \\
\text { Coronation of Vytautas and Thanksgiving } \\
\text { for Lithuanian Independence and Defence } \\
\text { of Freedom Day }\end{array}$ & $\begin{array}{l}15 \text { July } 1410 \\
8 \text { September } 1430\end{array}$ \\
\hline 1791, First Written Constitution in Europe Day & 3 May 1791 \\
\hline $\begin{array}{l}\text { 1791, Two nations (Lithuania and Poland) Mutual Vow } \\
\text { Proclamation Day }\end{array}$ & 20 October 1791 \\
\hline Press Restoration, Language and Book Day & 7 May 1904 \\
\hline Restoration of Lithuanian State Day & 16 February 1918 \\
\hline Lithuanian Armed Forces Day & 23 November 1918 \\
\hline Lithuania Minor Accession to the Lithuania Proper Act Day & 30 November 1918 \\
\hline Lithuanian Flag Day & 1 January 1919 \\
\hline The Constituent Assembly Day & 15 May 1920 \\
\hline The Day of Klaipeda Region & 15 January 1923 \\
\hline
\end{tabular}


(b)

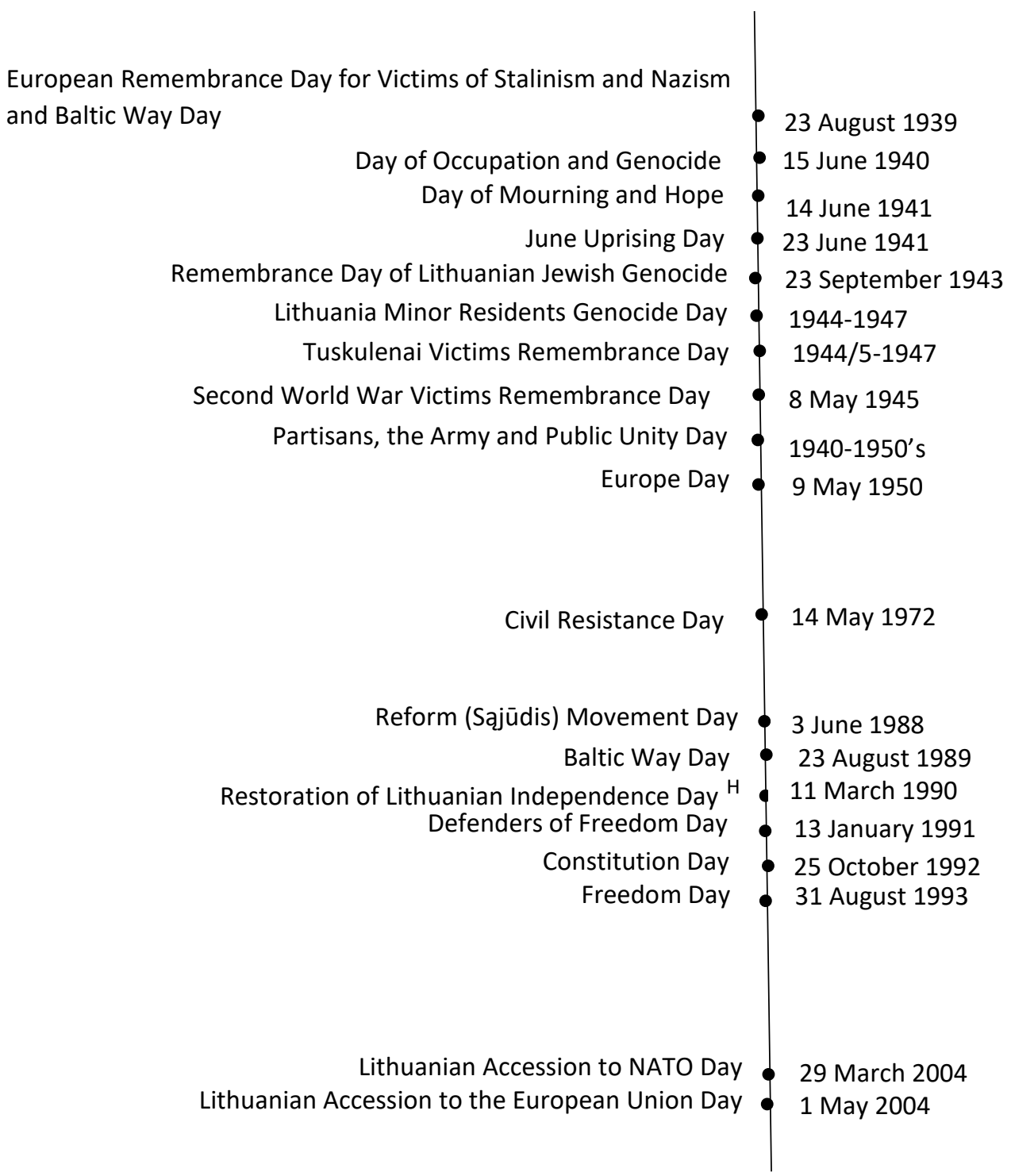

Appendix A: Lithuanian commemorgram (Source: compiled by the author, based primarily on Etar.lt, 2016) 
(a)

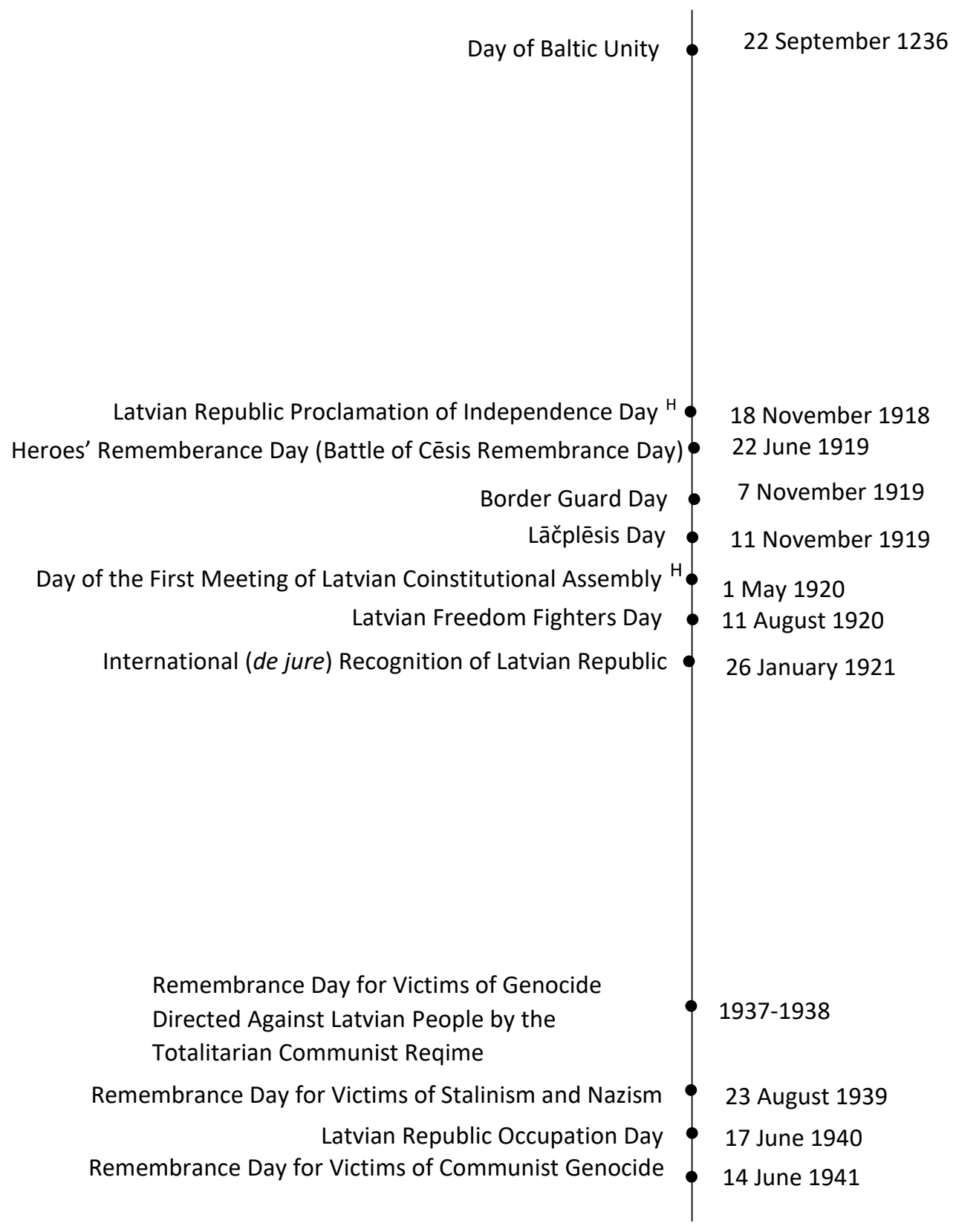


(b)

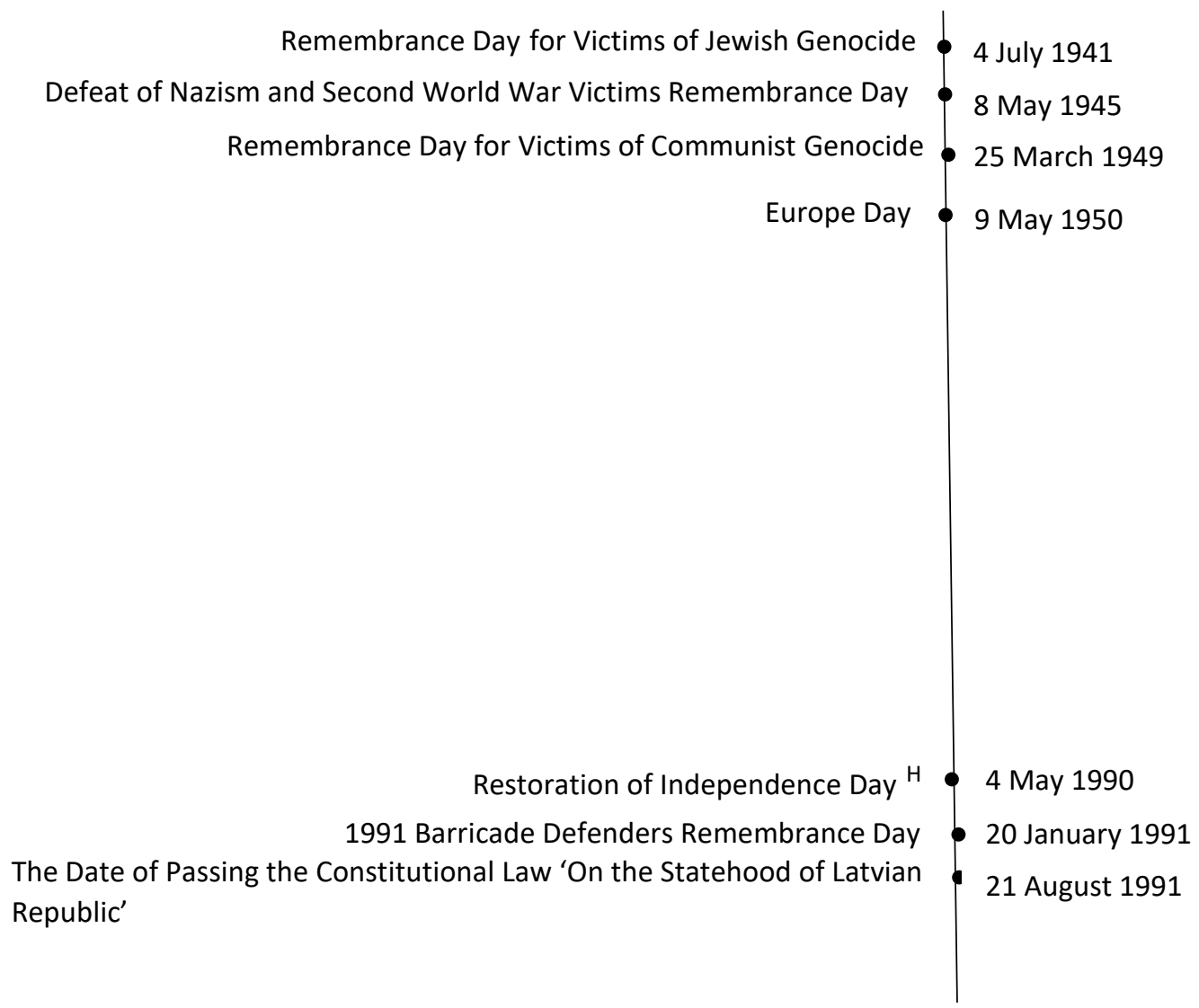

Appendix B: Latvian commemogram (Source: compiled by the author, based primarily on likumi.lv, 2015). 


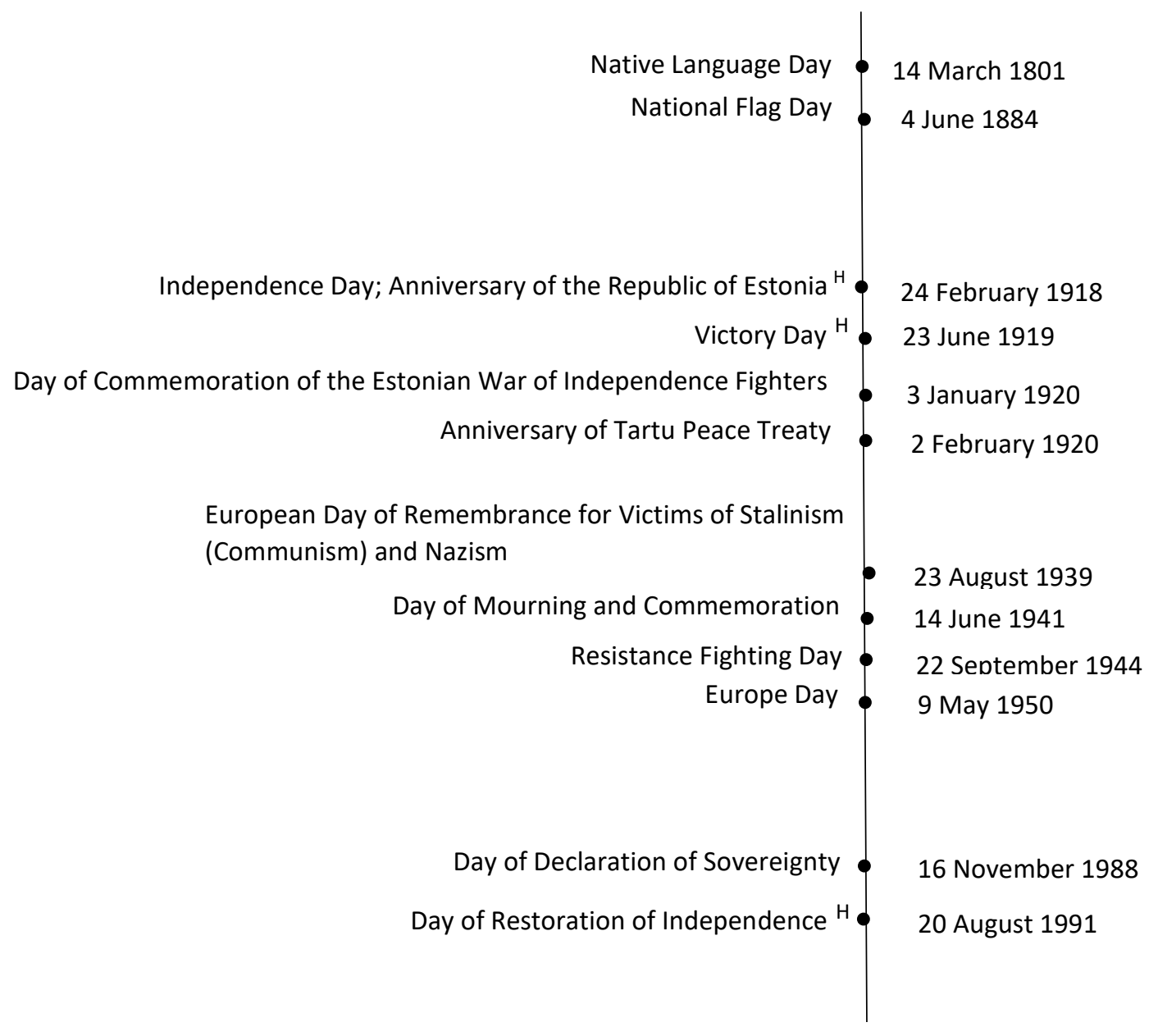

Appendix C: Estonian commemogram (Source: compiled by the author, based primarily on Eesti.ee, 2017). 


\section{References}

Assmann A (2004) Four Formats of Memory: From Individual to Collective Constructions of the Past. In: Emden C and Midgley D (eds) Cultural Memory and Historical Consciousness in the German-Speaking World Since 1500. Berlin: Peter Lang, pp.19-38.

Assmann A (2008) Transformations between History and Memory. Social Research 75(1): 49-72.

Assmann A (2015) Cultural and Political Frames of Forgetting. In: Galizia G and Shulman D (eds) Forgetting: An Interdisciplinary Conversation. Jerusalem: The Hebrew University Magnes Press, pp. 14-40.

Assmann A (2016) Shadows of Trauma. Memory and the Politics of Postwar Identity. New York: Fordham University Press.

Boldāne I (2006) “Labo Ulmaṇlaiku” mīta vitalitāte Latvijas iedzīvotāju apziṇā. In: Zellis K (ed) Mìti Latvijas vēsturē. Riga: Žurnāla 'Latvijas Vēsture' fonds, pp. 65-72.

Brüggemann K (2015) Celebrating Final Victory in Estonia's 'Great Battle for Freedom': The Short Afterlife of 23 June 1919 as National Holiday, 1934-1939. In: Tamm M (ed) Afterlife of Events. Perspectives on mnemohistory. Basingstoke: Palgrave Macmillan, pp. 154-177. 
Casquete J (2013) Commemorative Calendar and Reproduction of Radical Basque Nationalism. Politics, Religion \& Ideology 14(1): 21-35.

Cimdina A (2010) The genesis and perception of a national hero: Andrejs Pumpurs and Lāčplēsis beyond literary space. In: Cimdiṇa A and Hanovs D (eds) Latvia and Latvians. A People and a State in Ideas, Images and Symbols. Riga: Zinātne, pp.35-57.

Cossu A (2010) Memory, symbolic conflict and changes in the national calendar in the Italian Second Republic. Modern Italy 15(1): 3-19.

Cressy D (1996) National Memory in Early Modern England. In: Gillis RJ (ed) Commemorations. The Politics of National Identity. Second printing. Princeton, NJ: Princeton University Press, pp. 61-73.

David L (2014) Impression management of a contested past: Serbia's evolving national calendar. Memory Studies 7(4): 472-483.

Eesti.ee (2017) National, public and school holidays. Available at: https://www.eesti.ee/eng/topics/too_ja_ettevotlus/tooaeg_ja_puhkus/riiklikud_puhad_j a_lipupaevad (accessed 26 February 2017). 
Eglitis SD (2002) Imagining the Nation. History, Modernity, and Revolution in Latvia. University Park, PA: The Pennsylvania State University Press.

Eglitis SD and Ardava L (2014) Remembering the Revolution: Contested Pasts in the Baltic Countries. In: Bernhard M and Kubik J (eds) Twenty Years After Communism. The Politics of Memory and Commemoration. Oxford: Oxford University Press, pp. 123-145.

E-tar.It (2016) LIETUVOS RESPUBLIKOS ATMINTINŲ DIENŲ İSTATYMAS $1997 \mathrm{~m}$. liepos $3 \mathrm{~d}$. Nr. VIII-397. Lietuvos Respublikos Seimas/ Teisès akty registras. Available at: https://www.e-tar.lt/portal/It/legalAct/TAR.D570962773F8/WannxmVDGD (accessed 26 February 2017).

Etzioni A (2004) Holidays and Rituals: Neglected Seedbeds of Virtue. In: Etzioni A and Bloom J (eds) We Are What We Celebrate. Understanding Holidays and Rituals. New York: New York University Press, pp.1-42.

Fox EJ (2006) Consuming the Nation: Holidays, sports, and the production of collective belonging. Ethnic and Racial Studies 29(2): 217-236.

Fridman O (2015) Alternative calendars and memory work in Serbia: Anti-war activism after Milošević. Memory Studies 8(2): 212-226. 
Grybauskaite D (2016) Address by President Dalia Grybauskaitè at the Flag Raising Ceremony in Daukanto Square. Available https://www.Irp.It/en/activities/speeches/address-by-president-dalia-grybauskaite-atthe-flag-raising-ceremony-in-daukanto-square/24684 (accessed 29 May 2017).

Hackmann J and Lehti M (2012) Myth of Victimhood and Cult of Authenticity. Sacralizing the Nation in Estonia and Poland. In: Raudvere C, Stala K and Willert ST (eds) Rethinking the Space for Religion. New Actors in Central and Southeast Europe on Religion, Authenticity and Belonging. Lund: Nordic Academic Press, pp.126-162.

Himka PJ and Michlic BJ (eds) (2013) Bringing the Dark Past to Light. The Reception of the Holocaust in Postcommunist Europe. Lincoln, NE: University of Nebraska Press.

Hope N (1996) Interwar Statehood: Symbol and Reality. In: Smith G (ed) The Baltic States. The National Self-Determination of Estonia, Latvia and Lithuania. Reprint. London: Macmillan Press, pp.41-68.

Jõesalu K (2012) The Role of the Soviet Past in Post-Soviet Memory Politics through Examples of Speeches from Estonian Presidents. Europe-Asia Studies 64(6): 1007-1032. 
Jõesalu K and Kõresaar E (2013) Continuity or Discontinuity: On the Dynamics of Remembering 'Mature Socialism' in Estonian Post-Soviet Remembrance Culture. Journal of Baltic Studies 44(2): 177-203.

Kaprāns M (2016) Remembering communism in Latvia: a nationalizing state and the multidirectionality of the past. In: Gubenko I, Hanovs D and Malahovskis V (eds) The New Heroes - The Old Victims. Politics of memory in Russia and the Baltics. Riga: Zinātne, pp.74-107.

Kaprāns M and Saulītis A (2017) Latvijas sociālās atmiṇas monitorings. Ziṇojums Nr.2. Sociālās Atmiñas Pētniecības Centrs/ Latvijas Universitāte. Available at: http://www.academia.edu/32932266/Latvijas_soci\%C4\%811\%C4\%81s_atmi\%C5\%86as_m onitorings_2017 (accessed 13 July 2017).

Knutsen K (2016) Strategic silence: political persuasion between the remembered and the forgotten. In: Dessingue A and Winter J (eds) Beyond Memory. Silence and the Aesthetics of Remembrance. Oxon: Routledge, pp. 125-140.

Kõiva M (2013) Calendar feasts: Politics of adoption and reinstatement. In: Laineste L, Brzozowska D and Chłopicki W (eds) ESTONIA AND POLAND: Creativity and tradition in 
cultural communication Volume 2: Perspectives on national and regional identity. Tartu: ELM Scholarly Press, pp.59-82.

Kõresaar E (2016) Life story as cultural memory: making and mediating Baltic socialism since 1989. Journal of Baltic Studies 47(4): 431-449.

Korolova J, Badins Z, Kacane I, Laha I and Romanovska A (2015) A Festivity Calendar: Transformations and State Power in Latvia. In: 2nd International Multidisciplinary Scientific Conference on Social Sciences and Arts, Albena, Bulgaria, 26 August - 1 September 2015, Book 1, Volume 1, pp.273-280. Sofia: STEF92 Technology Ltd.

Kreegipuu T (2011) Tähtpäevakalendri kujunemisest Nõukogude Eestis aastatel 1945-1985. Tuna. Ajalookultuuri ajakiri 14(2): 68-90.

Kuznecovienè J (2008) Šventes švenčiantis lietuvis: bendruomeniškumo diapazonas. In: Čiubrinskas V and Kuznecovienė J (eds) Lietuviškojo identiteto trajektorijos. Kaunas: Vytauto Didžiojo Universitetas, pp. 75-88.

Lavi L (2013) Making time for national identity: theoretical concept and empirical glance on the temporal performance of national identity. Nations and Nationalism 19(4): 696-714. 
Lentz C (2013) Celebrating independence jubilees and the millennium: national days in Africa. Nations and Nationalism 19(2): 208-216.

Lietuva.It (2017) Restored State of Lithuania turns 100. Available at: http://www.lietuva.It/100/en/ (accessed 5 July 2017).

Lieven A (1994) The Baltic Revolution. Estonia, Latvia, Lithuania and the Path to Independence. Second edition. London: Yale University Press.

Likumi.Iv (2015) LATVIJAS REPUBLIKAS LIKUMS. Par svētku, atceres un atzīmējamām dienām. Available at: http://likumi.lv/doc.php?id=72608 (accessed 26 February 2017).

Ločmele K, Procevska O and Zelče V (2011) 8./9. Maijs Latvijā. In: Muižnieks N and Zelče V (eds) Karojošā piemiṇa 16.marts un 9.maijs. Riga: Zinātne, pp.236-276.

McCrone D and McPherson G (2009) Marking Time: The Significance of National Days. In: McCrone D and McPherson G (eds) National Days. Constructing and Mobilising National Identity. New York: Palgrave Macmillan, pp. 212-221.

Mälksoo M (2009) The Memory Politics of Becoming European: The East European Sublaterns and the Collective Memory in Europe. European Journal of International Relations 15(4): 653-680. 
Mälksoo M (2014) Criminalizing Communism: Transnational Mnemopolitics in Europe. International Political Sociology 8(1): 82-99.

Nora P (1989) Between Memory and History: Les Lieux de Mémoire. Representations 26: 724.

Ochman E (2013) Post-Communist Poland - Contested Pasts and Future Identities. Oxon: Routledge.

O'Connor K (2006) Culture and Customs of the Baltic States. Westport, CT: Greenwood Press.

Onken CE (2007) The Baltic states and Moscow's 9 May commemoration: Analysing memory politics in Europe. Europe-Asia Studies 59(1): 23-46.

Onken CE (2010) Memory and Democratic Pluralism in the Baltic States - Rethinking the Relationship. Journal of Baltic Studies 41(3): 277-294.

Pettai CE and Pettai V (2015) Transitional and Retrospective Justice in the Baltic States. Cambridge: Cambridge University Press. 
Plakans A (2011) A Concise History of the Baltic States. New York: Cambridge University Press.

Plate L (2016) Amnesiology: Towards the study of cultural oblivion. Memory Studies 9(2): 143-155.

Safronovas V (2014) Coming to Terms with the Dictatorial Past: Rising of Conservative Trend in Contemporary Lithuania. Studia Universitatis Cibiniensis: Series Historica 11(Suppl.): 133162.

Schwartz B (2008) Collective Memory and Abortive Commemoration: Presidents' Day and the American Holiday Calendar. Social Research 75(1): 75-110.

Schwartz B (2009) Collective Forgetting and The Symbolic Power of Oneness: The Strange Apotheosis of Rosa Parks. Social Psychology Quarterly 72(2): 123-142.

Senvaitytė D (2015) Annual Holidays in Lithuania: Discourse in the Press and the Reality in Daily Life. Lituanus 61(1): 48-71.

Skangale L (2011) Latvijas valsts svētku, atceres un atzīmējamās dienas. 4 izdevums. Riga: Zvaigzne $A B C$. 
Spillman L (1998) When Do Collective Memories Last? Founding Moments in the United States and Australia. Social Science History 22(4): 445-477.

Šutinienè I (2009) Tautos istorijos simboliai Lietuvos gyventojų tautinėje vaizduotèje: herojų jvaizdžiai ir jų kaita. Sociologija. Mintis ir veiksmas 1(24): 40-62.

Swain JA (2012) From Personal Sacrifice to Civil Resistance: National and Civic Identities in the Designation of May 14 as a National Memorial Day. Darbai ir dienos 57: 9-29.

Taagepera R (1993) Estonia. Return to Independence. Boulder: Westview Press.

Tamm M (2008) History as Cultural Memory: Mnemohistory and the Construction of the Estonian Nation. Journal of Baltic Studies 39(4): 499-516.

Tamm M (2013) In search of lost time: memory politics in Estonia, 1991-2011. Nationalities Papers 41(4): 651-674.

Vinitzky-Seroussi V and Teeger C (2010) Unpacking the Unspoken: Silence in Collective Memory and Forgetting. Social Forces 88(3): 1103-1122. 
Winter J (2010) Thinking about silence. In: Ben-Ze'ev E, Ginio R and Winter J (eds) Shadows of War. A Social History of Silence in the Twentieth Century. New York: Cambridge University Press, pp.3-31.

Zatlers V and Adamkus V (2007) STATEMENT by Valdis Zatlers, President of the Republic of Latvia, and Valdas Adamkus, President of the Republic of Lithuania. Available at: http://www.president.Iv/pk/content/?art_id=11540 (accessed 27 March 2017).

Zelče V (2004) Pirmās pēckara padomju laikagrāmatas: 1945. gadā izdotie kalendāri. Latvijas Arhivi 4: 107-121.

Zepa B, Kḷave E, Žabko O, Krastiṇa L, Bebriša I, Jansone Z, Vaivode L and Beriṇa L (2008) Mēs. Svētki. Valsts. Valsts svētku svinēšanas socioloǵiska izpēte. Riga: Baltic Institute of Social Sciences.

Zerubavel E (1996) Social memories: Steps to a sociology of the past. Qualitative Sociology 19(3): 283-299.

Zerubavel E (2003) Calendars and History: A Comparative Study of the Social Organization of National Memory. In: Olick KJ (ed) States of Memory. Continuities, Conflicts, and Transformations in National Retrospection. Durham, NC: Duke University Press, pp.315-338. 
Zerubavel E (2004a) Time Maps. Collective Memory and the Social Shape of the Past. Chicago, IL: The University of Chicago Press.

Zerubavel E (2004b) The social marking of the past: toward a socio-semiotics of memory. In: Friedland R and Mohr J (eds) Matters of Culture: Cultural Sociology in Practice. Cambridge: Cambridge University Press, pp. 184-195.

Zerubavel E (2010) The Social sound of silence: Toward a sociology of denial. In: Ben-Ze'ev E, Ginio R and Winter J (eds) Shadows of War. A Social History of Silence in the Twentieth Century. New York: Cambridge University Press, pp. 32-46.

Zerubavel Y (1995) Recovered Roots. Collective Memory and the Making of Israeli National Tradition. Chicago, IL: The University of Chicago Press.

\section{Author biography}

Starting from January 2018, the author is an Economic and Social Research Council and President's Doctoral Scholar Award funded PhD student at the University of Manchester. His current research interests include theories of collective memory, symbolic nationhood, everyday ethnicity and (post-)communist cities. 